attractively illustrated exposition of the state of genetics at the time.

Hurst was gifted with fine powers of observation. $\mathrm{He}$ had, too, enthusiasm for an idea and a capacity for sustained and pertinacious work, both of which he devoted whole-heartedly to the furtherance of genetical science. That he was somewhat lacking in critical faculty may have been due to the fact that he had not been through the academic 'mill'. He was fortunate, however, in that his collaboration with William Bateson brought him into close touch with a critical mind of the highest order. Without that influence he might have become more the gifted amateur than the solid contributor to the science that claimed his interest.

R. C. PunNetT

\section{Dr. Stephen Miall}

Trwe death of Stephen Miall on October 12, 1947, in his seventy-fifth year, inflicted on chemists an irreparable loss. Yet, paradoxically-and he enjoyed a paradox as much as any man-Miall was not a chemist at all. Of Yorkshire stock, with an inherited leaning towards science or, at any rate, towards natural philosophy, he was articled to his uncle, partner in a London firm of solicitors, when nineteen years old. He took prizes and the degree of LL.D., but right up to his end many hundreds of industrial chemists in Great Britain and elsewhere must have been entirely unaware that 'Doctor' Miall-that kindly, erudite, sociable, eclectic personality emerging almost as clearly from his editorials in Chemistry and Industry as from his twinkling eyes and grave smile, when one met him-was, in fact, a doctor of law and not of science at all.

Nevertheless, his contact with the chemical industry dates back to the beginning of the century, when he became very much concerned with the manufacture of white lead and, as a result, with the humanitarian aspect of that technology; that is, with lead poisoning as an industrial hazard, in connexion with which he more than once attended an International Labour Conference or discussions at the International Labour Office. Some time after qualifying in law, he also took a London B.Sc.

Miall's editorship of Chemistry and Industry began in 1922, and he remained at this post until two and a third years before his death. During his retiral, his health was not what his many friends and admirers had hoped for him; but he often found time and ability to join them at his favourite local haunt or in the Savage Club, where his wisdom, knowledge and slightly mordant wit, almost always mitigated by a cheerful grin, made him a most popular as well as a distinguished and unmistakable figure. $\mathrm{H}_{\Theta} \mathrm{had}$ great erudition, though it was wide rather than deep. $\mathrm{He}$ used it to illuminate both his attractively and, indeed, uniquely written editorials and his very deliberate but equally unique conversation, an art the apparent passing of which he always deplored. Homer and Horace as often furnished his readingand his quotations-as did the English classics : he know them all intimately.

Among his activities, besides his editorial work, have been the compiling of a light-verse anthology, "Poets at Play", active participation in the Society, of Yorkshiremen in London and 'The Catalysts' Club', and the writing and editing, jointly or alone, of books designed to strengthen the links between chemists, especially industrial chemists, and the non-soientific world, particularly that part of it concerned with the arts. It is not surprising that his death will be mourned by a large and varied collection of individuals, some of whom may never have met him and will therefore not experience the strong sense of personal loss that is common to all those who had.

A. L. B.

P. J. V.

\section{Prof. G. C. MacCurdy}

NEws has been received of the death in a road accident, at the age of eighty-four, of Dr. G. G. MacCurdy, the well-known prehistorian and professor emeritus of Yale University.

George Grant MacCurdy came from the southern branch of a well-known New England family, which had retained a close contact with Great Britain. He was a graduate of Harvard and of Yale, and from 1894 until 1898 he followed postgraduate courses in anthropology at the Universities of Paris, Berlin and Vienna. During 1900-31 he was successively lecturer in anthropology, assistant professor of prehistoric archæology, and research associate with the rank of professor at Yale University, and during the whole of this time he was also curator of anthropological collections. In 1921 he took a leading part in the foundation of the American School of Prehistoric Research, and was its first director, a post he held until last year, and in which he was supported by the collaboration of his wife, Janet Glenn Bartlett, whom he had married in 1919. His tenure of the directorship was marked by the organisation of many successful vacation tours in Europe, and by participation with various British funds and institutions in prehistoric excavations in Iraq, Palestine and Bulgaria.

This work was very close to Dr. MacCurdy's heart, and he was justly proud of the leading part played by a member of his own school, Theodore D. McCown, in the discovery of the new human fossil, Mount Carmel man, during 1931-32. His disinterested courage and vision in thus committing his school to a participation in field-work in which he himself was not free to take an active part has been of incalculable value to the advancement of prehistoric studies in the last twenty years, and will be his lasting monu. ment.

His friends and pupils will cherish an affectionate memory of a distinguished scholar with a singularly kindly, gentle and modest personality.

\section{A. E. GarroD}

\section{Prof. Max Planck, For Mem.R.S.}

Prof. J. R. Partington writes: I knew Planck as professor of theoretical physics in the University of Berlin. His course was spread over more than one year, and I began with the last and most difficult part, comprising thermodynamies, the theory of heat, relativity, and quantum theory, next year taking the first part, which dealt with general mechanics and the theory of deformable bodies. The lectures began at 9 a.m. in the University building in Unter den Linden ; they were very well attended, and there were always many standing around the room. As the lecture-room was well heated and rather close, some of the listeners would from time to time drop to the floor, but this did not disturb the lecture. The windows were all closed, partly because of the intense cold and partly because of the noise of the changing of the guard outside. There was also an 
exercise class, conducted by Planck himself, which nominally began at 8 a.m., but usually about 8.15 . The medical lectures began at 6 a.m., so the University building was well aired by that time.

Planck lived some distance away, in the Grünewald, and travelled into Berlin by the Stadtbahn. His train often ran parallel to the one I was in from Charlottenberg for a short distance, and Planck could be seen, in a compartment filled with clerks and shop-girls, conning his notes in preparation for the lecture. In the lecture itself he used no notes. He began by writing down a simple equation, but would soon be in the middle of a Fourier series, or, as in the theory of elasticity, a complicated equation which seemed to develop itself. He never made a mistake and never faltered. Very rarely he would take his notes out, look at the board, say "Ja", and put them back again. He spoke in a quiet, audible and pleasant voice, and was the best lecturer I ever heard. He had no mannerisms except one : he had two sticks of chalk before him in parallel arrangement, which he changed about in place from time to time when he was not writing; he had a small reading desk and did not walk about. The mathematies on the board was extremely neat and legible, even when German vector symbols were used, and was set out in systematic order.

Planck's method was to develop the subject logically from general principles, and even when short cuts were possible, he liked to bring each topic into its logical sequence in a general scheme. This made some of it hard going for such as myself. He disliked vector methods, and although he usually wrote the final result in vector form when desirable, the deduction was in terms of Cartesian or polar co-ordinates. He had two favourite sentences. One was "Wir können noch einen Schritt weitergehen", and the other "Jetzt ist die Sache vollständig genügend erledigt".

His lectures on sound included some theory of music, and he gave an extra demonstration with a special harmonium of the natural scale and its necessary modification, "während die praktische Musik, besonders seit der Einführung der Instrumente mit festen Tönen, mit einer endlichen, nicht $\mathrm{zu}$ zahlreichen Menge von Tönen auskommen muss".
Planck was just then developing the 'second' quantum theory of continuous absorption and discontinuous emission (which brought in the half quantum of zero-point energy). He was conservative, and a little shocked by Einstein's bold development of the photon. $\mathrm{He}$ was keenly interested in the impact of the quantum theory on general philosophical ideas, and shrank from the extreme view that its later phases removed the validity of the law of causality. To the rather pessimistic outlook which came over what was once regarded as the solid foundation of science he was unsympathetic. Theoretical physics had progressed, it is true, but to him it still had a meaning.

Prof. E. N. Da C. Andrade writes: "In the last paragraph of my obituary notice on Prof. P. Lenard (Nature, December 27, p. 895), I venture to refer to him as 'a dark genius'. Going through some old papers I have just found a letter, dated 1936, from a well-known German physicist whose name I refrain from quoting because of the difficulty, at the present time, of obtaining his permission. It contains the following passage which I have translated except for the actual quotation.

"I have found the following lines in Hebbel which refer there to the Lord God, but apply very well to Lenard in our Heidelberg time :

" "Und aus seinen Finsternissen tritt der Herr, soweit er kann'."

WE regret to announce the following deaths :

Prof. E. C. C. Baly, C.B.E., F.R.S., Grant professor of inorganic chemistry in the University of Liverpool during 1910-37, on January 3, aged seventy-six.

Prof. P. A. C. Dangeard, member of the Botanical Section of the Paris Academy of Sciences, on November 10 .

Dr. C. A. Mitchell, formerly editor of The Analyst, on January 5 , aged eighty.

Mr. W. H. Pick, of the Meteorological Office, on December 26, aged fifty-seven.

Prof. H. A. Prichard, White's professor of moral philosophy in the University of Oxford during 1928-37, aged seventy-six.

\section{NEWS and VIEWS}

\section{New Year Honours}

THE New Year Honours list includes the names of the following men of science and others associated with scientific and university work :

G.C.I.E. : Sir Maurice Gwyer, vice-chancellor of the University of Delhi.

G.B.E. : Sir Edward Mellanby, secretary of the Medical Research Council.

K.B.E. : Sir James Irvine, principal and vicechancellor of the University of St. Andrews.

Knights : Prof. F. C. Bartlett, professor of experimental psychology, University of Cambridge; $\mathrm{Mr}$. H. Claughton, recently principal of the University of London; Dr. J. D. Cockeroft, director of the Atomic Energy Research Establishment, Ministry of Supply ; V. Z. de Ferranti, chairman and managing director of Ferranti, Ltd. ; Dr. W. Ivor Jennings, vice-chancellor of the University of Ceylon; The Hon. C. J. Lowe, chancellor of the University of
Melbourne; H. R. Ricardo, chairman and technical director, Ricardo and Co., Ltd.; Dr. R. V. Southwell, rector of the Imperial College of Science and Technology, London.

C.B. : Dr. G. M. Bennett, Government chemist.

C.S.I. : W. T. Hall, chief conservator of forests, United Provinces, India.

C.M.G. : A. P. Mitchell, director of land surveys, Palestine: W. A. Robertson, forestry adviser to the Colonial Office.

C.I.E.: J. Petty, chief conservator of forests, Sind ; W. D. West, director of the Geological Survey of India ; Dr. R. E. Mortimer Wheeler, directorgeneral of archæology, India.

C.B.E. : H. W. Bennetts, principal of the Animal Health and Nutrition Laboratory, Western Australia ; G. L. T. Brough, deputy director of electrical engineering, Admiralty; J. C. Bugher, director of the Yellow Fever Research Institute, Yaba, Lagos, 